\title{
DEMOCRACY AND SECURITY IN WEST AND SOUTHERN AFRICA
}

\section{Albert Domson-Lindsay}

Dr Domson-Lindsay is a critical social theorist/free-lance researcher in Swaziland and a former doctoral scholar and occasional lecturer in the Politics and International Studies Dept, Rhodes University, South Africa

P O Box 1140, Nhlangano, Swaziland

Tel: +268 2077152

e-mail: albertdomsonlindsay@yahoo.co.uk

\begin{abstract}
This paper offers a comparative analysis of security and democracy in West and Southern Africa. It examines the popular notion that political liberalism leads to security, maintaining that it is too elitist, statist and exclusive to offer socio-economic security to all the regions' peoples. The paper shows that state-driven regional institutions stifle public participation in their decision-making and implementation processes. So, to attain a harmonious balance between democracy and security, this paper proposes an institutionalised democratic ethos anchored in a discursive or deliberative culture. This will ensure the interests of all: people, state and capital.
\end{abstract}

The prospects for peace arguably have less to do with democracy in its liberal sense, and more to do with questions of socio-economic distribution, or a deepened understanding of democratic questions.

Tandeka Nkiwane 2001, p 286

The principle of political life should be agreed, as far as possible, by all.

Andrew Linklater 1993, p 9 


\section{INTRODUCTION}

States in Africa have been variously described as 'weak' (Clapham 1996; Rothchild 1987), 'lame' (Sandbrook 1985), 'soft' (Herbst 1996), 'collapsing', 'failing', 'failed' (Swatuk 2001), 'retreating' (Strange 1996), 'fictive' (Callaghy 1984) and 'quasi' (Migdal 1988). In one sense this suggests that the state faces a series of crises, including internal legitimacy problems and armed conflicts.

Most people feel alienated or marginalised from the political and economic processes. This alienation can take the form of mass protests or public boycotts: civil society groups protest against excessive commercialisation of social services and, in some instances, boycott payment of basic services. In Swaziland and Zimbabwe the monopoly of political space and the brutal suppression of dissenting voices by the regimes create social tensions which periodically break out into social unrest. The legitimacy crisis can also take on violent dimensions. Consider these examples in West Africa:

- Liberia experienced a period of civil conflict that lasted from 1990-2003.

- Sierra Leone was next, and Côte d'Ivoire, since 2002, has descended into civil chaos.

- The Senegalese government has not successfully contained the secessionist movement in the Casamance province (Essuman-Johnson 2005, p 46).

- The governments of Mali, Niger and Burkina Faso have, since the 1980s, been battling against their minority Tuareg populations, who feel marginalised (Olukoshi 2001; Abramovici 2004).

- Nigeria, the economic powerhouse of the region, has its own internal instability. Militant groups like the Oduduwa Peoples Congress (a Yoruba group), the Movement for the Survival of Ogoni People, the Movement for the Emancipation of the Niger Delta, the Niger Delta Peoples Volunteer Force and the Ijaw Youth Council - the last four are all in the oil-producing region of Nigeria - have sprung up to challenge the government. Their objectives include greater autonomy and control of resources in their respective regions (Mail \& Guardian 23-29 September 2005, p 15; Ikelegbe 2001; Watts 2001). The goal of these militant groups conflicts with the monopolistic tendency of the Nigerian state and this conflict sometimes culminates in violent clashes between the state and armed groups. In fact, a low-intensive civil conflict simmers in the Niger Delta between the Nigerian military and the militant groups.

Similarly, in Southern Africa, legitimacy crises have led to armed conflicts in some states. We take two examples: 
- Lesotho descended into civil chaos in 1998 and South Africa, with Zimbabwe and Botswana, intervened to restore order (Vale 2003). But, as Rok Ajulu (2002) has pointed out, the Lesotho crisis is cyclical because each election year rekindles the civil strife as the political elites and the military jostle for power and wealth.

- The Democratic Republic of Congo (DRC) remains a conflict zone. The hope that liberal democratic elections in the DRC will lead to stability is tenuous, especially because rebel forces continue to fight against government troops in the eastern Congo and an elite struggle for the state continues (Mail \& Guardian 11-17 June 2004, p15).

This domestic instability invariably assumes a regional dimension. Armed conflict in one state spills over into neighbouring states and engulfs a region (Clapham 2001). So, the civil war in Liberia spilled into Sierra Leone; the latter conflict, in turn, 'precipitated instability in Guinea'; and now Côte d'Ivoire, which has been an oasis of peace and stability, has succumbed to the civil war contagion in West Africa (Wannenburg 2005, p 9). In fact the Liberian civil war assumed a regional dimension from the 1990s. The Economic Community of West African States' Monitoring Group (Ecomog) initially intervened on behalf of the government in Monrovia while Côte d'Ivoire and Burkina Faso tacitly backed Charles Taylor's National Patriotic Front of Liberia (NPFL) (Clapham 2001, p12; see also Magyar \& Conteh-Morgan 1998).

The same is true of Southern Africa. In the past, the apartheid state supported rebel movements in Mozambique (Renamo) and Angola (Unita). The conflict in South Africa affected the region. States like Zambia, Tanzania and Zimbabwe supported the liberation movements, providing bases for them, while the apartheid regime carried out a destabilisation campaign against neighbouring states. More recently, the armies of Southern African states such as Angola, Zimbabwe and Namibia supported the DRC government, while Rwanda and Uganda backed the rebel factions (Bischoff 2006, p160).

An unstable environment is seldom conducive to meaningful regional cooperation, integration or development. The reason for this is clear. Any viable regionalist project depends on the flows of capital, goods and people; interrupting these signals a reversal. Moreover, instability and legitimacy crises can compel governments to focus disproportionately on consolidating their authority rather than on regional issues. Even when attention is drawn to the region, the regional governments focus more on state and regional security than on developmental issues.

This brings us to this question: how can the legitimacy crisis be resolved? In a post-Cold War world political liberalism has been advanced as a credible model 
for reordering the state, and liberal interventionism is the standard operating procedure for putting the state back together after it has been ravaged by civil conflict. The next section examines these views and practices.

\section{THE LIBERAL DEMOCRATIC DISCOURSE AND PRACTICE: A PANACEA FOR THE CRISIS OF THE STATE?}

After the end of the Cold War most states in West and Southern Africa adopted liberal democratic constitutions, as a result of pressures from popular movements, donor nations, and the international financial institutions. The United States, in particular, has exerted pressure on regimes in the regions to adopt liberal democracy (Abrahamsen 1997; Ake 2000). For instance, it threatened to impose sanctions on the Nigerian government when President Ibrahim Babangida attempted to renege on his pledge to conduct presidential elections on 12 June 1993; in the event, he changed his mind. In Malawi, the suspension of an aid package of \$174-m by donor nations compelled Kamuzu Banda, the late Malawian President, to hold a referendum on a multiparty system and to accept the outcome (Ake 2000, p129). Similar external influences contributed to the adoption of liberal democracy by governments in Ghana, Côte d'Ivoire, Benin, Zambia, Tanzania, Togo and Cameroon (Ake 2000, p 129).

Initially, the International Monetary Fund (IMF) and the World Bank seemed reluctant to impose democratic conditions on client states. The rationale was that to do so would violate the principle of non-interference in the affairs of clients. Publicly, certainly, the interest of the IMF and the World Bank was limited to the promotion of sound macro-economic policies. However, they revised their policy of non-interference and embraced the prevailing orthodoxy of a link between democracy and economic development. The belief is that liberal democracy makes the rulers accountable to the ruled. The former pursue policies that reflect collective interests rather than selfish ones. They do this in order to continue staying in power (Ake 2000, pp 77-8; see also Abrahamsen \& Williams 2002, p 317). In addition, political liberalism protects private property, which - for liberals - helps to facilitate accumulation, which is essential for economic growth and development.

Western interest in the African democratic project is ironic, especially when set against the Cold War. Then, democracy was not a valued currency in the West's interaction with Africa, notwithstanding the lip service paid to it. Essentially, Cold War relationships rested on strategic calculations. The former United States Secretary of State, Warren Christopher, alluded to these interests:

During the long Cold War period policies toward Africa were often determined not by how they affected Africa but whether they brought 
advantage or disadvantage to Washington or Moscow. Thankfully we have moved beyond the point of adopting policies based on how they might affect shipping lanes next to Africa rather than the people in Africa

Cited in Ake 2000, p 139

So, the superpowers supported authoritarian regimes in Africa. For instance, in the 1980s, the United States gave military and financial assistance to leaders like Samuel Doe of Liberia, Daniel arap Moi of Kenya and Mobutu Sese Sekou of Zaire (Clapham 1996; Ake 2000). In South Africa the undemocratic apartheid regime was supported by Western powers under the pretext that the country was a bulwark against communism. Why then were African states pressurised to adopt liberal democracy after the Cold War? What was the motive behind it? The answer lies in the democratic peace theory, to which we now turn.

\section{THE DEMOCRATIC PEACE THEORY ${ }^{1}$}

Theoretical interest in liberal democracy in the post Cold War world is anchored in the work of Kant, Rousseau, Schumpeter, Cobden and other classical liberals who argued that liberal democratic states are peaceful while authoritarian ones endanger international stability (Burchill 1996). Immanuel Kant asserted that democratic or republican states do not like wars because the rulers are constrained by a constitution according to which the consent of the people must be secured before the state can go to war. The people, however, do not desire war because they bear its human and financial costs. Both Kant and Schumpeter believed that autocratic states have a propensity for war, which contrasts with the pacifism of liberal states. Schumpeter argued that authoritarian rulers in the 19th century delighted in waging war for personal gain. War expanded the national coffers because citizens were taxed in order to secure adequate funds for military campaigns (Burchill 1996).

Both Kant and Rousseau maintained that republican states promote domestic harmony because they are based on self-government and self-legislation - the constitution is the expressed will of the citizens and the civil liberties enshrined in it give people the right to participate in affairs of state (Kant 1970; Burchill 1996; Devetak 2002). So, for Kant and other classical liberals, the republican state

1 This theory rests on a central proposition that democratic governments, free trade, and international law promote global peace and order. These assumptions were first made by classical liberals and there is now a growing literature of democratic peace theory which tests their empirical validity (see McGrew 2002, p 276). 
'was an essential building block of peaceful international order' (McGrew 2002, p 270). Richard Cobden, for his part, claimed that free trade creates interdependence between people and states. This promotes peace because citizens and governments come to realise that war will impose on them more economic costs than benefits (McGrew 2002, p 270).

At international level Kant recommended the formation of a confederation of republican states founded on shared commitment to interdependence, democracy, peace and prosperity. He argued that the success of this 'select club' of liberal states can induce others to join by embracing its rules and norms (see McGrew 2002). Kant further argued that the spread of liberalism and the deepening of global economic interdependence can culminate in the expansion of the liberal zone of peace.

Michael Doyle (1983), through empirical analysis, claimed to have discovered what Kant had proposed - a pacific union of liberal democratic states. Doyle (1983, p 213) discovered that 'there is a predisposition against warfare between liberal states ... [that] a liberal zone of peace, a pacific union, has been maintained and has expanded despite numerous particular conflicts of economic and strategic interests'. Echoing Kant and other classical liberals he suggests that this peace is the result of the restraining influence of a liberal constitution, the international respect for individual rights, and shared commercial interests.

Conversely, Doyle and other democratic peace theorists, following Kant, argue that non-liberal states are predisposed to violate the sovereignty and territorial integrity of other states, especially the liberal ones. These states are, in a sense, 'at war with their people' because they 'lack internal legitimacy' (see Griffiths 1999, p 66). Given these conditions, liberal governments have the right to wage war against non-liberal states. In fact, liberals or democratic peace theorists see this mission as an opportunity to expand the zone of peace.

This also explains why modern liberals like Michael Doyle and Francis Fukuyama have suggested that the end of communism presents an opportunity for liberal governments to extend the democratic zone of peace beyond its Western core. For Fukuyama (1989) the demise of communism is a vindication of the universalistic claims and eternal values of liberalism. According to him and other modern liberals exporting liberal democratic values will ensure domestic and international peace and prosperity. This background explains why African states were urged to adopt, or coerced into adopting liberal democracy after the Cold War.

The liberal democratic peace discourse is, however, contentious. To begin with, the Kantian Republic is not the same as the 'real existing liberal state' (Brown 1996, p 31); the former comprises 'civil associations' in which there is collective participation in decision-taking process. So, the probability for peace will be 
greater in such a polity than in a real existing liberal state. Decision-making in liberal democratic states is often monopolised by bureaucrats and by ruling and interest group elites. These groups make cost-benefit calculations on a different basis: they may desire war because it furthers their interests (Brown 1996).

The assumption that liberal democratic states do not go to war against each other can be challenged. Michael Doyle argued that despite the colonial rivalries between France and Great Britain the two nations formed an 'entente' against illiberal Germany in 1914, and the US renounced its isolationist policy to join the allied powers in 1917. But it is not certain that the peace between these liberal democratic states could have been sustained if there had been no common enemy - Germany. Similarly, the threat to the capitalist system posed by the then Soviet Union in the post-1945 period compelled the liberal democratic states to 'rally behind the leadership of the other' (Brown 1996, p 41). This explanation invariably leads to the question: would they have remained pacifist towards each other in the absence of an external common enemy? Certainly, there cannot be an easy answer, essentially because there has never been a self-contained world of liberal states. So, the assumption that liberal states are generally peaceful and do not engage in war against each other remains a conceptual one.

In fact, for Chris Brown (1996), the possibility of perpetual peace is anchored in rationality. This argument echoes a Kantian view that human beings become 'amenable to reason' when they calculate the costs and benefits of war. Kant (1977, p 189) believed that human beings will be 'compelled to ensure that war, the greatest obstacle to morality and the invariable enemy of progress, first becomes gradually more humane then more infrequent and finally disappears completely as a mode of aggression. Although Kant and Doyle see this rationalism as a peculiar quality of liberal democratic states the ability to engage in cost-benefit analysis of war cannot be an exclusive characteristic of these states. Rather, all states are capable of 'working out the consequences of action and are not in the grip of some kind of death wish' (Brown 1996, p 43). We turn now to consider the state of liberal democracy in the two regions.

While most states in Southern Africa have embraced liberal democracy it has not opened up space for viable forms of opposition to develop and, more importantly, for people to participate directly in the affairs of the state. Although states like South Africa, Namibia and Botswana are nominally liberal democratic states, they are de facto one-party states, and too much power is concentrated in the hands of the president (Southall 2003, p 268). Furthermore, the ruling regimes are often less accountable to the public. For example:

- The structure of the South African electoral system effectively takes away the monitoring function and power of the electorate. 
Parliamentarians are not directly elected by the people, rather they are appointed by the political parties (Southall 2003, p 267).

- Zimbabwe represents a classic case of the futility of liberal democracy in Southern Africa - authoritarianism co-exists with political liberalism. Elections are rigged, opponents are intimidated and harassed, and the regime is noted for its 'contempt for the people' (Southall 2003, p 268).

- In Namibia, as in South Africa, political parties select representatives to Parliament.

Many writers have pointed out that liberal democracy is elitist, exclusionary and hegemonic (Zeleza 1997; Mkandawire 1999; Ake 2000; Laakso \& Olukoshi 2001; Nkiwane 2001; Good 2002; Southall 2003). At the continental level, the late Claude Ake (2000) showed that when the democratic wave broke on the shores of Africa in the 1980s the political elites used the idea for their own benefit. In countries like Zambia, Malawi, and Nigeria, elites who were out of power used the ballot box to get back into power. In Ghana, Côte d'Ivoire and Cameroon incumbent elites exploited the democratic process to legitimise their rule and to further themselves: they established and controlled the electoral bodies, subverted the electoral rules and regulations, and abused the election process (Adejumobi 1998, pp 41-42; Saxena 2002, p 80).

Liberal democracy is largely restricted to periodic elections. Roger Southall (2003, p 269), following Kenneth Good, wrote:

Democracy in southern Africa is centred around electoralism, is otherwise fairly hollow, and does not, on the whole, make a lot of difference to ordinary people's lives.

The only visible role for the citizens, for the most part, is electing the political elites. Political liberalism, then, is a convenient framework in which the national elites compete with each other for political power and resources. It is a mechanism, therefore, that seeks the acquiescence of citizens to the social order.

The advent of liberal democracy has not resolved the problem of the disempowerment and marginalisation of minority groups. To consolidate their power ruling elites withdraw the citizenship of subaltern groups and other formidable political opponents to deny them the right to vote. This accentuates internal social conflict as excluded groups contest their exclusion from the political process. For instance, the ongoing civil crisis in Côte d'Ivoire was sparked by the denial of Ivorian citizenship and the right to vote to northern minority groups, largely because they were perceived as migrant communities (Herbst 2000; Zeleza 1997; Bassett 2003). 
Southall (2003, p 268), echoing Good, shows the similarities between the intent of contemporary political liberalism and its 19th-century counterpart:

\begin{abstract}
Liberal democracy ... [in the 19th century] ... arose ... as a means of incorporating the masses into politics in an orderly way, not through 'irrational', participatory interventions such as strike action, but in voting for competing elites at periodic elections. The old democratic ideals of justice and equality were shorn-off as dangerously ideological, while Lockean beliefs in the rights of individual property ownership remained. Elitism accompanied by popular passivity came to characterize the main tendencies within the liberal form of democracy.
\end{abstract}

In effect, it perpetuates the systematic exclusion of the majority of people from the political process. Does it have the potential to bring order or stability to the states in West and Southern Africa? Tandeka Nkiwane (2001, p 286) provides an answer:

The spread of liberal democracy and consumer capitalism has not resolved many of the contradictions in Africa, but has rather in many cases exacerbated internal socio-political struggles, externalized in a variety of forms ... On the African continent, the prospects for peace, arguably, have less to do with democracy in its liberal sense, and more to do with questions of socio-economic distribution, or a deepened understanding of the democratic question.

For Chris Brown the liberal democratic project is rather a 'fragile plant' (1996, $\mathrm{p} 43$ ) because it intrinsically concentrates power in a few hands, which undermines its ability to promote lasting peace (1996, p 42).

Attempts to democratise the regional processes remain frozen at the rhetorical level. Both SADC and the Economic Community of West African States (Ecowas) have, in principle, enshrined in their constitutions the right of civil organisations to participate in the regional process. In practice, however, there is little commitment by regional governments to allow civil society involvement in the policy-formulation process. In fact, the democratisation project seems to be limited to formal institutions such as the SADC Parliamentary Forum and the Ecowas Parliament which comprise representatives from national parliaments - members of the ruling class, who do not necessarily represent the interests of all the regions' peoples. The parliamentary bodies perform only advisory functions. The regional

2 At the turn of the century SADC moved away from a functional approach to co-operation and embraced free-trade regionalism. 
development project turns on neo-liberalism, ${ }^{2}$ which often favours a transnational capital class and its local agents (see Söderbaum 2001). We turn now to liberal interventionism.

\section{LIBERAL INTERVENTIONISM}

Many analysts argue that the polarisation of the Cold War days has been replaced by a globalist mode of thinking: states are more willing now than in the past to co-operate with each other for political and economic stability (Brown 2002; Devetak 2002; Lawson 2002). The Agenda for Peace by Boutros Boutros Ghali, former United Nations Secretary General, which appeared in the last decade of the 20th century, called for the renewal of partnership between the UN and states in order to promote international security (Henrikson 1995). The appeal was timely: it came just as the Cold War ended. George H W Bush, the 41st President of the US, in the same period, sensed the dawn of a New World Order - a world in which liberal democratic states come together to fight against the forces that threaten global security. This optimism sprang from the international solidarity against the Iraqi invasion of Kuwait in 1990, when the US and her allies, with the backing of the UN Security Council, restored sovereignty to Kuwait (Falk 2005, p 197).

The new order does not only mean - to retrieve the expression of E H Carr (1945, p 54) - 'coming to the aid of an attacked country against its attacker', it also means that the $\mathrm{UN}$ and the international society can intervene in civil conflicts, and especially in contexts where the state is on the verge of disintegration. They intervene to reconstruct the state on liberal democratic lines, to restore 'democracy by force' (cited in Vale 2003, p 131; see also Von Hippel 2000). This process follows a standard operating procedure: once a truce has been secured the UN-mandated force intervenes to perform peace-keeping or peace-making functions; a brokered settlement is followed by a transitional government of national unity; the intervention force demobilises ex-combatants, who are re-integrated into the society; finally, the transitional government (assisted by the UN) conducts multiparty elections, after which a new government is installed. This leads us to the question how altruistic is this form of liberal interventionism?

Notwithstanding the humanitarian undertones of Boutros Boutros Ghali's Agenda for Peace, its primary point of reference is the sovereign state - the sovereignty and territorial integrity of the state (Henrikson 1995; Devetak 2002; Lawson 2002). This is why David Campbell debunks the popular view that the sovereign state is undermined by liberal interventionism (Lawson 2002, p 213). For David Campbell liberal or other intervention revitalises sovereignty. Put differently, the purpose of intervention is to restore state sovereignty that has been displaced by conflict or the collapse of the state. In addition, when states 
come together to intervene in civil conflicts they reaffirm the sovereign basis of the inter-state system (Campbell 1995; Lawson 2002, p 213). James Rosenau (2002, $\mathrm{p} 26)$ fingers the sovereign and statist motive of intervention:

When an internal war ravages a society and leads to a collapse of the state, the unquestioned impulse in the halls of government everywhere is to rebuild the state.

An examination of the motives of Ecowas/Ecomog and extra-regional actors in the Liberian Civil War reveals concerns about the stability and sovereignty of the Liberian state and the viability of the inter-state system in the region.

This explains why regional leaders such as President Ibrahim Babangida of Nigeria, Sir Dawda Jawara of the Gambia and President Lansana Kouyate of Guinea perceived the Liberian civil conflict in 1989 as a recipe for regional instability. Charles Taylor's insurrection in Liberia set a precedent in the region because it was the first civilian attempt to overthrow a military government in West Africa. The thoughts of two presidents captured the mood of the regional leaders. Sir Dawda Jawara warned:

If Charles Taylor with the support of what I may call mercenaries from other countries of the sub-region were to come to power by force, one can imagine the implication it will have for sub-regional security.

West Africa 28 November-2 December 1990

President Kouyate deplored the precedent being set by Taylor: 'Charles Taylor is a bad example. Civilians should not be encouraged to overthrow military regimes' (New Africa October 1992, p 16).

In the end, military force was deployed to reconstruct the sovereign state of Liberia and to affirm the sovereignty of the regional inter-state system. The intervention followed a regular liberal interventionist path: peacekeeping and peacemaking exercises, the establishment of a transitional government of national unity, demobilisation and rehabilitation of combatants and the organisation of democratic elections. At the end of the process Charles Taylor, a warlord, emerged as President of Liberia in 1997. However, barely two years later, Liberia relapsed into civil war.

In late 2003 the regional actors and extra-regional actors like the United States, in partnership with the UN, again began the ritualised response to the Liberian question. Ecowas and US soldiers were deployed to keep the peace; a transitional government was installed; the process of disarmament, demobilisation, rehabilitation and re-integration was initiated, and democratic elections were held 
in October 2005 (The News (Monrovia) 7 April 2004; UN News Service 10 April 2004). Similar statist-oriented responses were employed in Sierra Leone and Guinea Bissau in West Africa and in the DRC and Lesotho in Southern Africa. Despite these efforts, the regions are not stable. Côte d'Ivoire, as we have noted, is embroiled in civil conflict. Similarly, the DRC remains unstable: there is renewed fighting in eastern Congo (SAFM News Bulletin 5 December 2006; see also Mail \& Guardian 11-17 June 2004, p 15). There are growing fears in Sierra Leone that the state may revert to anarchy once the UN forces leave (Africa Today October 2005, $\mathrm{p}$ 35). The stability in Lesotho is tentative: elite struggles for the state resurface in every election year (Ajulu 2002). The contestation by the opposition of the recent election results makes this point clear. This brings us to this question: Why has the liberal order failed to bring social cohesion and lasting security to the regions?

Liberals like Schumpeter (1950) believe that the role of people in the democratic process must be limited to renewing, in elections, the mandate of political elites to govern. Schumpeter and other liberals believe that most ordinary members of society are uninterested in public affairs and, more importantly, do not have the relevant technical or intellectual abilities to understand the complexities of modern issues (this contention is, however, contestable). As a result, it is the task of bureaucrats and elected representatives to act and take decisions on behalf of the public. However, in practice, these governing elites often do not decide and act for the 'social good'; rather they administer society for the 'market good', which furthers their own interests (Chachage 2004, p 251).

This neglect of the public interest is at variance with the fundamental (liberal) idea of elections: citizens choose their representatives to champion their common interest - for instance, to address issues of poverty, unemployment and inequality. Therefore, the subversion of the public mandate by ruling elites leads to continuous social-political tensions and other forms of insecurity. As we have seen, elections in a liberal democratic setting are opportunities for elites to compete for state power; but this rivalry can also take a violent turn in a 'zero-sum game': political elites mobilise disenchanted social groups to challenge electoral outcomes and to counter their marginalisation from the political process. This explains why 'electoral engineering' is offered up as a strategy to accommodate the interests of political opposition while ordinary citizens remain disempowered and alienated.

However, the prospects for universal security and development in the regions depend on 'deliberative', 'participatory', 'discursive' or 'popular' democracy. ${ }^{3}$

3 This form of democracy originated with the Greeks. There was popular participation in the political affairs of the society. Political practice was an inter-subjective communicative process which made possible unconstrained 'reciprocal speech'. In this political community the individual, in interacting with other members, learned to harmonize his or her interests with that of the group - it was, therefore, a meeting point between ego and alter ego (Bernstein 1995, p 35). 
This form of political practice reflects an innate human desire for selfdetermination and equality. Its basic requirement is that the individual must have an equal opportunity to 'shape the social conditions that affect his / her life' (Held 2003, p 471). This will ensure the realisation of 'generalisability' of interest through 'reasoning from the point of view of others' (Held 2003, p 472; see also Habermas 1987). This rational, social point of view is manifested in Habermas's 'ideal speech situation' or discourse ethics, ${ }^{4}$ Rawls's original position, and Barry's formulation of impartialist reasoning (Held 2003, p 472; see also Rawls 1971).

The discursive form of democracy requires the restoration of civil society to the public sphere, as was the case in 18th-century Europe. In that era social groups like craftsmen, landed gentry, nobles and commoners, who had been 'excluded from the then dominant institutions of government' (Bernstein 1995, p 38), met in salons and parliaments to discuss affairs of state (Calhoun 1996, p 453). Their goal was to make the state 'more open, accountable, and responsive to interests beyond those of the traditional elites' (Bernstein 1995, p 38).

They assembled as autonomous individuals and participated in debates based on 'rational argument and criticism' (Calhoun 1996, p 453). Opinions formed by consensus invariably influenced public decisions (Calhoun 1996, p 453). So, this opinion-generating space, which is now the 'province ... of bureaucrats, credentialed experts and interest group elites' (Calhoun 1996, p 454), is the domain of cultural, economic, domestic and significantly political interactions between private individuals and associations outside the direct control of the state (Held 1996, p 315; Habermas 1992; Calhoun 1996). In a sense, this political practice entails an interactive process between the state and 'the communications of the public sphere'. For Habermas, this relationship is vital because the public sphere, which is made up of civic movements, is an opinion-forming space, while the formal institutions make decisions. So, rationally formed public opinions ought to 'point the use of administrative power in specific directions' (Habermas 1992, p 300). This procedure ensures that the interests of forces of social solidarity which are formed in 'widely differentiated autonomous public spheres' are realised 'against the two other mechanisms of social integration: money and administrative power' (Habermas 1992, p 363). ${ }^{5}$

4 Discourse ethics fundamentally promotes dialogue among all those significantly affected by particular social arrangements. It creates a communicative community in which partners engage in a rational interchange of ideas, views or opinions: in this community all relevant voices are heard; the best of all available arguments, given the present state of our knowledge, are accepted, and only the non-coercive coercion of the better argument determines the affirmations and negations of the participants (Dews 1992, p 260). This community thus rests on foundations of rationality, consensus, self-determination and equality. It also promotes fairness and justice.

5 Habermas uses 'money' as a reference to powerful economic forces and 'administration' as a reference to the state. 
We now come to a central question. Can the state and other institutions of authority in the regions be compelled to institutionalise discursive political practice?

Most states in West and Southern Africa have liberal constitutions containing a raft of individual rights and obligations - legal, economic, social and political. These rights allow individuals or groups to take legal action against institutions such as the state and corporate entities on grounds of violation of rights.

Social groups in the two regions have taken advantage of these rights to initiate, for example, legal litigation against their governments and transnational corporations. The Treatment Action Campaign (TAC) - an AIDS activist group in South Africa - took the government to the Constitutional Court over its refusal to make anti-retroviral drugs available to HIV sufferers. The court ruled in favour of the TAC, instructing the government to provide the drugs.

Similarly, social movements in West Africa have exercised their fundamental human rights by seeking compensation for transnational corporate activities which impact negatively on their social and environmental rights. Several communities in the Niger Delta - the oil-producing region of Nigeria - sued petroleum companies like Chevron and Shell in Nigerian, British and US courts. Their grievances centred on the adverse effects of oil exploration on the environment, their livelihood and their health. The courts, in most cases, awarded financial compensation to the claimants.

So, a space exists, in a liberal climate, 'for the extension and radicalisation of existing rights'. Social forces can use these individual rights to demand institutionalisation of discursive practices bound by law and the provision of relevant social and material conditions which could help produce rational, objective, and universal outcomes (Habermas 1992, p 370). We now examine briefly some of these conditions.

People can participate constructively in a discursive process if they have access to relevant information, expert advice, and adequate understanding of issues. This is important because only an enlightened public can form a rational opinion (Coleman \& Nathanson 2003). So, the various institutions of authority are obliged to provide the relevant information, the material incentives and other forms of assistance to enable the public to come to an enlightened decision on issues.

The opinions generated should, by law, permeate decisions of formal institutions. We now examine some avenues for public participation in the affairs of the two regions. ${ }^{6}$

6 Although the focus is largely on the regions the suggestions are equally relevant to the individual states. 


\section{THE INTERNET AS A VIRTUAL COMMUNITY}

Coleman \& Nathanson (2003) suggest that the internet can help bring Europe's people into the decision-making processes of the European Union. These scholars believe the internet could be used as a 'virtual public sphere' to facilitate dialogue between ordinary European citizens and regional policy-makers. The citizens would ask questions and express their views in this social space. The policymakers would be obliged to respond to citizens' questions by, for example, explaining their actions, providing relevant information, and embodying people's interests in policies.

This virtual community can be nurtured in both Southern and West Africa. This would address the problem of distance and scale and help sustain the interest of the public in the affairs of the regions. Furthermore, civil society groups could create independent virtual social spaces and pass on their recommendations reached through consensus - to the relevant institutions. Sangonet, for instance, which is a coalition of civil groups in South Africa, uses the internet to disseminate information to other civil society organisations in the region. This could be expanded into a regional public sphere. The opinions generated should be transmitted by a civil society unit established at the regional secretariat to the relevant formal institutions.

Special occasions like holidays provide platforms for public discourse on regional affairs. Indeed, they present an opportunity for an interchange of ideas between representatives of formal institutions and the public. Ecowas has a public holiday which is usually spent on speeches on the work of the organisation (Lavergne 1997). However, it could also serve as an occasion for dialogue.

\section{CONVENTIONS}

A convention or summit is a formal or informal gathering which brings together people from diverse social backgrounds to discuss pertinent issues affecting their lives. The subject is either a single issue or a combination of issues like unemployment, the constitution, the environment and development. It therefore constitutes an appropriate public forum for discussing both national and regional affairs.

David Runciman (2003) offers useful insights into how a regional convention of civil society could be constituted. He suggests that the various parliamentary constituencies in the states that make up the European Union could choose delegates outside the formal party system to deliberate on issues in a regional convention. Runciman believes these representatives should be ordinary citizens rather than politicians. With access to the relevant information and a good 
understanding of issues, it is likely that these individuals, who represent no particular interest, could initiate a discourse. Each participant would express his / her views freely, listen to others, and be prepared to defend his / her own opinion against those of others. The consensual opinions reached at such conventions should then be embodied in policies.

In addition, civil society organisations in the two regions could hold a summit before the annual inter-ministerial conferences which precede the summits of heads of state in the two regions. The suggestions emanating from the civil society meeting, like those of the inter-ministerial conferences, should form the basis of the decisions of the heads of state.

\section{PARTNERSHIP}

Both SADC and Ecowas have technical or specialised commissions that deal with specific regional issues like security, energy, environment, trade, natural resources, communication and tourism (Page \& Bilal 2001, p 5; Bischoff 2002, p 290; Rene 2004). Civil society representatives involved in these issues could be invited to collaborate with the specialised bodies. Such partnerships would ensure that the interests and needs of the relevant public are articulated and catered for.

\section{REFERENDUM}

The word referendum dates back to the middle of the 19th century. It is usually described as the 'referring back of a decision to the people' (Runciman 2003, p 11). There are two categories of referendum: 'initiative' and 'plebiscitary' (Runciman $2003, \mathrm{p} 11$ ). The former gives citizens an opportunity to 'frame policy' and to veto or 'repeal an already existing law which they don't like' (Held 1996, p 322; Runciman 2003, p 11). It represents an effective means of popular participation in the policy-making process. 'Plebiscitary' referenda (Runciman 2003, p 11) are so called because they are 'consultative' (Held 1996, p 323). This is the form used by most states and is normally related to 'matters of constitutional change' (Runciman 2003, p 11). This type of referendum represents an attempt to inject a participatory moment into politics. There have been instances when the popular will expressed through such a referendum has been at variance with the expectations of the politicians and ruling elites. For example, the people of Zimbabwe, in a referendum in 2000, rejected the government's wish to 'expand the presidential powers' of Robert Mugabe to confiscate land from white farmers, rather than abiding by the 'willing buyer willing seller' policy (Moore 2001, p 255).

The European Union uses plebiscitary referenda to seek approval for its policies, recommendations and treaties - they are a way of involving the European 
public in the affairs of the organisation. This opportunity, however, does not exist in either West or Southern Africa where regional protocols and treaties are ratified by national parliaments. The European example could be adopted in the two regions, which would give the regions' peoples the opportunity to participate in the regional process.

\section{CITIZEN JURY / JURIES}

Held $(1992,1996)$ and Barber (2003) suggest that popular participation in the political process can be promoted by institutionalising 'citizen jury/juries, especially at local and national levels. The concept of citizen jury/juries is borrowed from the judicial system in countries like the United States. A brief description of this process will help illustrate its importance.

In this legal procedure the jurors selected to adjudicate cases are members of society who do not have a technical knowledge of the law. However, their verdicts are regarded as rational and legitimate because they are based on informed knowledge, relevant information and discursivity. How? Briefly, once the members of the jury have been selected they are secluded from the rest of society. This is done to remove all possible forms of external influences and pressures. The jurors have access to relevant information about the case, which includes evidence of witnesses, arguments, and counter-arguments from both the defence and the prosecution teams. They deliberate at the end of the court proceedings and come out with a consensual opinion which is read out by the presiding judge as the verdict.

In the political process the citizen jury would be selected on class, gender, ethnic, professional or age lines to assess the strengths and weaknesses of controversial policies and express opinions on issues like the environment, transport, social welfare and development. The citizen jury - like its 'judicial' counterparts - would comprise ordinary members of society with no expert knowledge. To ensure a high quality of discourse the jury must have expert advice and adequate information about and understanding of the agenda. This must be provided by the state and other institutions of authority. The opinions and recommendations of the jury should filter into decisions. This brings us to a pertinent question: What available resources could social forces use to legitimise their involvement in regional affairs?

\section{INSTITUTIONALISING DISCURSIVE PRACTICE}

Both Ecowas and SADC recognise, in their treaties, the right of civil society to participate in their respective affairs (Rene 2004, p 29). But, as we have seen, this 
right is more rhetorical than real. However, the provision legally entitles civil society organisations to participate in regional affairs. They can also use this entitlement to demand institutions which reflect the interests of the people. This would necessitate the restructuring of the existing legislative and judicial structures, which are presently subordinated to the wishes of governments.

Both the Ecowas Parliament - inaugurated in 2001 in Abuja, Nigeria - and the SADC Parliamentary Forum - constituted in 1996, with its Secretariat in Windhoek, Namibia, have only advisory functions (Rene 2004, p 14; Bischoff 2002). In the absence of substantive legislative authority the SADC Parliamentary Forum performs tasks like popularising the work of SADC and dispatching electoral observers to monitor elections in member states (Bischoff 2002, p 295). The Ecowas Parliament only makes recommendations to the 'appropriate community institutions' on issues like 'human rights [and]... social affairs' (Rene 2004, p 14). Put simply, these bodies reflect the interests of states.

Ecowas has a Court of Justice (Lavergne 1997; Rene 2004, p 14) and the SADC Draft Protocol on the Free Movement of Persons provides for a regional tribunal (Lavergne 1997; SAFM News Bulletin August 2005). The heads of state - the authority - appoint the judges, who only adjudicate in disputes relating to treaty violations between states. The court's decision is not binding on states and citizens from member states have no legal standing before the court (Rene 2004, p 13).

The court only accepts cases brought by the state on behalf of its citizens. Indeed, the court is superfluous, because the states do not use it: they prefer to use diplomatic means to resolve disputes. The grievances of citizens, which are usually against the state, never get to the court. The role of the Ecowas Court contrasts markedly with that of the European Court. European citizens can take legal action against their governments and the court's decisions are binding on states. To reiterate, how can civil society organisations legitimise their involvement in regional affairs?

First, civil society groups in the two regions must call for parliaments with legislative powers over regional issues. These institutions should, in turn, incorporate in their constitutions the right of public participation in the legislative process. This has to be an interactive process in which the rational communications of the diverse public spheres (such as environment, security and development) are represented in formal legislation. Second, civil organisations should press for strong and independent regional judiciary institutions like human rights courts. These courts or tribunals would have the power to adjudicate cases between the formal institutions of authority and civil society and the authority to enforce their decisions. They should also defend the right of civil society to participate in the regional process. 


\section{CONCLUSION}

What are the implications of institutionalised discourse in the two regions? To begin with, it would imply the end of state sovereignty. The state's monopoly over decision-making processes would be broken because popular forces would acquire the right to participate in these processes. However, this would not lead to a withering away of the state and other formal institutions of authority. Civil society would not have the power to govern itself or bring the entire society under its control.

We have seen that in the procedural interaction between civil society and formal institutions the former only generates opinions for the latter to act on. Yet civil society organisations in both regions would have sufficient legal power to make the political system act responsibly and democratically. This would help release the public persona of the state and would act for the general good of society. The state would be compelled to institute measures to reduce the capacity of private forces to distort the economic and political processes (Held 1996; Baker 2000). It would be obliged to be responsive to both individual and communal interests.

Citizens in both regions would come to have significant leverage over the organisations and institutions which affect their lives. This would help correct the democratic deficit that overlays them. The regional institutions will be compelled to enact laws and promote programmes which cater for both private and collective interests.

It is clear that an institutionalised discursive process facilitating mutual interaction between state and people has the potential to bring about security in the two regions. This is so because it establishes a legitimate order based on rationality, consensus, justice, fairness and democracy; it seeks to foster common interests, common aspirations and common goals. This is in marked contrast to the existing liberal democratic order, which is rooted in elitism, systematic exclusion, inequality and injustice. These invariably lead to insecurity.

\section{— REFERENCES}

Abrahamsen, R. 1997. 'The Victory of Popular Forces or Passive Revolution? A Neo-Gramscian Perspective on Democratization'. Journal of Modern African Studies, 35(1).

__ \& P Williams. 2002. 'Britain and Southern Africa: A “Third Way" or Business as Usual'. In K G Adar \& R Ajulu (eds). Globalization and Emerging Trends in African States' Foreign Policy Making Process - A Comparative Perspective of Southern Africa. Hampshire: Ashgate Publishing Ltd. 
Abramovici, P. 2004. 'United States: The New Scramble for Africa'. Review of African Political Economy 102.

Adejumobi, S. 1998. 'The Crisis of Elections and Democracy in Africa'. Africa Quarterly Delhi 38(2).

Africa Today 2005, October.

Ajulu, R. 2002. 'Survival in a Rough Neighbourhood: Lesotho's Foreign Policy in the Era of Globalization'. In K G Adar \& R Ajulu (eds). Globalization and Emerging Trends in African States Foreign Policy-Making Process - A Comparative Perspective on Democratization. Hampshire: Ashgate Publishing Ltd.

Ake, C. 2000. The Feasibility of Democracy in Africa. Dakar: CODESRIA.

Baker, B. 2000. 'Who Should Be Called to Account for Good Governance in Africa?' Democratization 7(2).

Barber, R. 2003. Strong Democracy. Berkeley and Los Angeles: University of California Press.

Bassett, J J. 2003. 'Dangerous Pursuit, Hunter Associations (Donzo Ton) and National Politics in Cote d'Ivoire'. Africa 73(1).

Bernstein, J M. 1995. Recovering Ethical Life: Jurgen Habermas and the Future of Critical Theory. London and New York: Routledge.

Bischoff, P H. 2002. 'How Far, Where To? Regionalism, the Southern African Development Community and Decision-Making into the Millennium'. In K A Adar \& R Ajulu (eds). Globalization and Emerging Trends in African States' Foreign Policy-Making Process: A Comparative Perspective of Southern Africa. Hampshire, England: Ashgate Publishing Ltd.

2006. 'Towards a Foreign Peacekeeping Commitment: South African Approaches to Conflict Resolution in Africa'. In W Carlsnaes \& P Nel (eds). In Full Flight: South African Foreign Policy after Apartheid. Midrand: Institute for Global Dialogue.

Brown, C. 1996. 'Really Existing Liberalism, Peaceful Democracies and International Order'. In R Fawn \& J Larkins (eds). International Society after the Cold War. London: Macmillan Press.

--_--. 2002. 'The Normative Framework of Post-Cold War International Relations'. In S Lawson (ed). The New Agenda For International Relations. Malden, MA: Blackwell Publishers Ltd.

Burchill, S. 1996. 'Liberal Internationalism'. In S Burchill \& R. Linklater (eds), Theories of International Relations. New York: St. Martin's Press.

Calhoun, C. 1996. 'Social Theory and the Public Sphere'. In B Turner (ed). The Blackwell Companion to Social Theory. Oxford, UK and Cambridge, USA: Blackwell.

Callaghy, T. 1984. 'The State as Lame Leviathan: The Patrimonial Administrative 
State in Africa'. In Z Erges (ed). The African State in Transition. New York: St. Martin's Press.

Campbell, D. 1995. 'The New Mindset of International Relations: Security, Sovereignty and Responsibility in Co-operating for Peace'. In S Lawson (ed). Agenda for Global Security: Co-operating for Peace and Beyond. St. Leonards: Allen and Unwin.

Carr, E H. 1945. Nationalism and After. London: Macmillan.

Chachage, C S L. 2004. 'Higher Education Transformation and Academic Exterminism $\square$ : The Case of SouthAfrica'. In T A Aina et al (eds). Globalization and Social Policy in Africa. Dakar/Senegal: CODESRIA.

Clapham, C. 1996. Africa and the International System. Cambridge: Cambridge University Press.

—. 2001. 'Rethinking African States'. African Security Review 10(3).

— , G Mills, A Morner \& E Sidiropoulos (eds). 2001. Regional Integration in Southern Africa: Comparative Perspectives. Johannesburg: South African Institute of International Affairs.

Coleman, C \& B Nathanson. 2003. 'E-Coverage of Europe'. In M Bond (ed). Europe, Parliament and the Media. London: The Federal Trust for Education and Research.

Cox, R. 1981. 'Social Forces, States and World Orders: Beyond International Relations Theory'. Millennium: Journal of International Studies 10(2).

Devetak, R. 2002. 'Signs of a New Enlightenment? Concepts of Community and Humanity after the Cold War'. In S Lawson (ed). The New Agenda for International Relations. Malden, MA: Blackwell Publishers Ltd.

Dews, P. 1992. Autonomy and Solidarity: Interviews with Jurgen Habermas. London and New York: Verso.

Doyle, M. 1983. 'Kant, Liberal Legacies, and Foreign Affairs' Parts 1 and 2. Philosophy and Public Affairs 12.

Essuman-Johnson, A. 2005. 'The State in West Africa: The Crisis of Production, Democracy and National Identity'. In W A Fawole \& C Ukeje (eds). The Crisis of the State and Regionalism in West Africa: Identity, Citizenship and Conflict. Dakar: CODESRIA.

Falk, R. 2005. 'Re Imagining the Governance of Globalization'. In A J Bellamy (ed). International Society and its Critics. Oxford: Oxford University Press.

Fukuyama, F. 1989. 'The End of History?' The National Interest 56.

Good, K. 2002. The Liberal Model and Africa: Elites Against Democracy. London: Palgrave. Griffiths, M. 1999. Fifty Key Thinkers in International Relations. London/New York: Routledge.

Habermas, J. 1987. The Theory of Communicative Action, Vol 2, Lifeworld and System: A Critique of Functionalist Reason. Cambridge: Polity. 
- 1992. Between Facts and Norms: Contributions to a Discourse Theory of Law and Democracy. Cambridge: Polity.

Held, D. 1992. 'Democracy: From City States to a Cosmopolitan Order?' Political Studies XL.

1996. Models of Democracy. Cambridge: Polity Press.

—. 2003. ‘Cosmopolitanism: Globalization Tamed?' Review of International Studies 29.

Henrikson, A. 1995. 'The Growth of Regional Organizations and the Role of the United Nations'. In L Fawcett \& A Hurrell (eds). Regionalism in World Politics: Regional Organization and International Order. Oxford: Oxford University Press. Herbst, J. 1996. 'Responding to State Failure in Africa'. International Security 21(3).

- 2000. States and Power in Africa. Princeton: Princeton University Press.

Ikelegbe, A. 2001. 'The Perverse Manifestation of Civil Society: Evidence From Nigeria'. The Journal of Modern African Studies 39(1).

Kant, I. 1970. Kant's Political Writing. Cambridge: Cambridge University Press. . 1977. Kant's Political Writings (trans H B Nesbit). Cambridge: Cambridge University Press.

Laakso, L \& A O Olukoshi. 2001. Challenges to the Nation State in Africa. Helsinki: University of Helsinki.

Lavergne, $\mathrm{R}(\mathrm{ed}) .1997$. Regional Integration and Co-operation in West Africa: a Multidimensional Perspective. Trenton, NJ and Asmara, Eritrea: Africa World Press.

Lawson, S. 2002. 'After the Fall: International Theory and the State'. In S Lawson (ed). The New Agenda for International Relations. Malden, MA: Blackwell Publishers.

Linklater, A. 1993. ‘Community, Citizenship and Global Politics'. Oxford International Review 5(1).

Magyar, K P \& E Conteh-Morgan (eds). 1998. Peacekeeping in Africa: ECOMOG in Liberia. New York: St. Martin Press.

McGrew, A. 2002. 'Liberal Internationalism: Between Realism and Cosmopolitanism'. In D Held \& A McGrew (eds). Governing Globalization: Power, Authority and Global Governance. Cambridge: Polity Press.

Mail \& Guardian 11-17 June 2004.

—. 23-29 September 2005.

Migdal, J. 1988. Strong Societies and Weak States: State-Society Relations in the Third World. Princeton: Princeton University Press.

Mkandawire, T. 1999. 'Crisis Management and the Making of Choiceless Democracies'. In R Joseph (ed). State, Conflict and Democracy in Africa. Boulder: Lynne Rienner

Moore, D. 2001. 'Is the Land the Economy and Economy the Land? Primitive Accumulation in Zimbabwe'. Journal of Contemporary African Studies 19(2). 
New Africa 16 October 1992.

Nkiwane, T. 2001. 'Africa and International Relations: Regional Lessons for a Global Discourse'. International Political Science Review 22(3).

Olukoshi, A. 2001. West Africa's Political Economy in the Next Millennium: Retrospect and Prospect. Dakar: CODESRIA.

Page, S \& S Bilal. 2001. Regional Integration in Western Africa. London: Overseas Development Institute.

Rawls, J. 1971. A Theory of Justice. Cambridge, MA: Harvard University Press.

Rene, R. 2004. The Social Dimensions of Regional Integration in ECOWAS. Working Paper No 4.

Rosenau, J. 2002. 'Ageing Agendas and Ambiguous Anomalies: Tensions and Contradictions of an Emergent Epoch'. In S Lawson (ed). The New Agenda for International Relations. Malden, MA: Blackwell Publishers Ltd.

Rothchild, D. 1987. 'Hegemony and the State Softness'. In E Zak (ed). The African State in Transition. New York: St. Martin Press.

Runciman, D. 2003. 'Politicians in a Fix'. London Review of Books.

SAFM News Bulletin. 5 December 2006.

August 2005.

Sandbrook, R. 1985. The Politics of Africa's Economic Stagnation. Cambridge: Cambridge University Press.

Saxena, S C. 2002. 'Democratic Revival in Africa: Is it Sustainable?' In A Zegeye \& P Ahluwalia (eds). African Identities: Contemporary Political and Social Challenges. England: Ashgate Publishing Ltd.

Schumpeter, J. 1950. Capitalism, Socialism and Democracy. New York: Harper Brothers. Söderbaum, F. 2001. 'The Dynamics of Security and Development Regionalism in Southern Africa'. In N Poku (ed). Security and Development in Southern Africa. London: Praeger.

Southall, R. 2003. 'Democracy in Southern Africa: Moving Beyond a Difficult Legacy'. Review of African Political Economy 96.

Strange, S. 1996. The Retreat of the State: The Diffusion of Power in the World Economy. London: Cambridge University Press.

Swatuk, L A. 2001. 'The Brothers Grim: Modernity and International Relations in Southern Africa'. In K C Dunn \& T M Shaw (eds). Africa's Challenge to International Relations Theory. New York: Palgrave.

The News (Monrovia). 7 April 2004.

UN News Service. 10 April 2004.

Vale, P. 2003. Security and Politics in South Africa: The Regional Dimension. Boulder, Colorado: Lynne Rienner Publishers.

Von Hippel, K. 2000. Democracy by Force: U.S. Military Intervention in the Post-Cold War World. Cambridge: Cambridge University Press. 
Wannenburg, G. 2005. 'Organized Crime in West Africa'. African Security Review $14(2)$.

Watts, M. 2001. 'Community, Extraction, and Political Ecology of a Mythic Commodity'. In N L Peluso \& M Watts (eds). Violent Environments. Ithaca and London: Cornell University Press.

West Africa. 28 November-2 December 1990.

Zeleza, P. 1997. Manufacturing African Studies. Oxford: CODESRIA. 